\title{
Jonathan Gross
}

\section{Byron's Masks of Devotion}

This essay argues that Byron's devotion was religious, personal, and political. If the meaning of the word "devotion" extends from religious to secular objects, so too Byron's own life followed a trajectory from Scottish Presbyterianism to a poetical skepticism that found expression in Manfred, Cain, and Don Juan. Considered by Matthew Arnold to be one of two leading English Romantic poets (the other was Wordsworth), Byron devoted himself to Greek Independence and inspired democratic movements throughout Spain, Portugal, and Italy.

George Gordon was an English poet, born in Scotland, who became Lord Byron at the tender age of ten. His first volume of poems, Fugitive Pieces and Hours of Idleness, were the work of an amateur aristocratic author. A harsh review by Henry Brougham in the Edinburgh Review, led him to lash out against his contemporaries in English Bards and Scotch Reviewers (1809), a biting satire written in the style of heroic couplets and epigrammatic wit popularized by Alexander Pope. Two years abroad gave him experience of Portugal, Spain, Malta, Greece, and Albania, where he began Childe Harold's Pilgrimage, the poem that made him famous (1812). He wrote several Eastern tales, including "The Giaour", which inspired painters such as Eugene Delacroix, and wrote Manfred, Mazeppa, and his epic satire and masterpiece, Don Juan. Byron spent his final year aiding the Italian Carbonari in their struggles to liberate themselves from Austrian rule, and in Greece, to free that country from Turkish occupation. Byron died of fever in Messolonghi, Greece, inspiring many members of London Greek Committee to join the Philhellenic cause. Though born a Scottish Calvinist, Byron struggled with religious, poetic, and political forms of devotion, the three categories that form the subject of this essay.

Byron's diverse expressions of devotion to women, poetry, friends and 
country was remarkable, perhaps the most remarkable thing about him. For a poet who held "constancy" up to ridicule, who once ridiculed George III for constancy to a "bad, ugly woman", Byron parsed devotion and faith in interesting ways, ways that blended over into political devotion. He famously wrote against the apostasy of Wordsworth, Southey, and Coleridge, and argued that if one begins with a political party, such as the Whigs, one should remain devoted to them and see that devotion through. Byron certainly did that. Having called Venice the "greenest isle of his imagination", he produced some of his best art there, before dying in and for a country to which he was equally devoted, Greece.

The Oxford English Dictionary defines devotion as primarily a religious term: "Devoted to divine worship". ${ }^{2}$ Eschewing a narrowly religious meaning of the word, I explore Byron's devotion to writing, to animals, to nature, women, religion, and political causes. A cautionary note is necessary, however, for John Cardinal Newman (1801-1890), the leader of the Oxford movement that hoped to turn Anglican forms of worship back to Catholic liturgical rituals, wondered if poetry could be separated from religious devotion. "If the unruly passions of a Byron made for rhetoric, only mildness, restraint of emotion, calmness of judgment-in short, the Christian virtues-could produce true poetry; for "a right moral state of heart" seemed clearly to Newman "the formal and scientific condition of a poetical mind." ${ }^{3}$ Having failed to develop such Christian virtues, at least in the narrow sense, ${ }^{4}$ Byron devoted himself to political causes such as Italian and Greek independence. "I am sorry Lord Byron is dead," Southey wrote, "We shall now hear his praises from every quarter. I dare say he will be held up as a martyr to the cause of Greek liberty, as having sacrificed his life by his exertions on behalf of the Greeks. Upon this score, the liberals would beatify him." For Southey, devotion was akin to martyrdom, sacrifice, exertion and, ultimately beatification. For Romantic poets, interested in making what Keats called a secular temple in a vale of soul-making, the world provided many opportunities for devotion that could take a poet from poetry to canonization in the political realm. ${ }^{6}$ Though he had John Keats, Matthew Arnold, ${ }^{7}$ and then Cardinal Newman to draw on, T.E. Hulme was the first to define Romanticism as "spilt religion," a dismissive term by a confirmed classicist that influenced T.S. Eliot and led to the disparagement of Romanticism in the first half of the 20th century. ${ }^{89}$ 


\section{Religious Devotion}

"I deny nothing, but doubt everything," Byron announced to Francis Hodgson in 1811. That a single author could inspire monographs with such disparate titles as Lord Byron: Christian Virtues and Byron as Skeptic and Believer reveals that Byron's sense of devotion has confounded critics for over two hundred years. Despite writing such religiously engaged works as Manfred, Heaven and Earth and Cain, and inspiring Shelley's "Julian and Maddalo", Byron represents the paradox of a man thoroughly conversant with scripture who nevertheless was accused of being an unbeliever. Whether we turn to his conversations with William Kennedy or to critical studies by Michael Cooke, ${ }^{10}$ Terence Hoagwood, or to more recent efforts by Emily Bernhard Jackson and Tony Howe, ${ }^{11}$ Byron's skepticism would seem to leave devotion out of the question. In his "Prayer to Nature", for example, Byron presented a pagan's view of the world, avoiding specific mention of a Christian deity who created it. In Manfred, Byron borrows the scoffing language of a Faust figure, only to become overwhelmed by the beauty of the natural world. More characteristic, however, is the "all-blasting tree" depicted in Childe Harold in Canto III (1818) which shows how man's suffering hardly justifies the cosmic creation; man is, as Byron suggested in "Prometheus" (1816), a "troubled stream from a pure source" (ln. 48), who has been left, unfairly, to suffer. This is the perspective of Paradise Lost and it is the viewpoint Byron provides in much of his verse, even in Don Juan, where he turns questions of religious belief to burlesque. The church-going and book-expurgating Donna Inez, the imperious hypocrite and sexually jealous Gulbeyaz, and the power-hungry, sexually-harassing Catherine the Great, not to mention the masquerading cross-dresser and stalker, duchess de Fitz-Fulke, all use masks of devotion to conceal erotic intent. Like other truth tellers who were Calvinists-John Milton and Herman Melville come to mind-Byron tore the tinsel of sentiment from love, as he wrote to his publisher about Don Juan. ${ }^{12}$

Byron's view of devotion can be found in two key passages. The first is from Manfred:

How beautiful is all this visible world!

How glorious in its action and itself!

But we, who name ourselves its sovereigns, we, 
Half dust, half deity, alike unfit

To sink or soar, with our mix'd essence make

A conflict of its elements, and breathe

The breath of degradation and of pride. ${ }^{13}$

In this passage, Manfred offers a view reminiscent of Augustine's Manicheanism in Confessions. ${ }^{14}$ Good and evil are at war. The natural world is beautiful, but man corrupts it. Man is born free, "and everywhere he is in chains", as Rousseau wrote in his Social Contract. ${ }^{15}$ The play depicts a war in the stars themselves, between outdated forms of worship practiced by Zoroastrians who celebrate brother-sister love as the highest form, and Christianity, with its proscriptions against such acts. Byron was a cultural relativist: he piqued himself on befuddling Orthodox Christians by comparing and contrasting other forms of belief which he encountered in his travels. He did so with William Harness, Francis Hodgson, and his wife, Annabella Milbanke. In facetious and intellectually playful letters, he contrasted the fervent religiosity of the Turks, for example praying five times a day, with the superficial pieties of the Anglican English, attending Church once a week. "I see not much difference between ourselves and the Turks," he wrote, "save that we have foreskins and they none, that they have long dresses and we short, and that we talk much and they little. In England the vices in fashion are whoring and drinking, in Turkey, sodomy and smoking, we prefer a girl and a bottle, they a pipe and a pathic." ${ }^{16}$ When he fought for, or rather supported, those who fought for Greek independence, Byron was as concerned with succoring the Turkish women and children as he was in raising a band of unruly Suliotes to conquer them.

In Hebrew Melodies he considered the sublime beauty of the Jewish form of worship, with its terror of a distant God's judgment. "Oh Weep for Those" and "The Harp the Monarch Minstrel swept "as well as "Jephtha's Daughter" and "She Walks in Beauty like the Night" were some of Byron's most popular lyrics, reaching an audience of over ten thousand. Overcoming the objections of his otherwise devoted banker Douglas Kinnaird, Byron befriended Isaac Nathan, whose music was written for John Braham, a fashionable and famous tenor. Perhaps because he sensed that we were all damned, regardless of our creed ("Believe those unbelievers, the Jews, he wrote in Don Juan, "who must be believed though they believe not you" [5:62]), he was ecumenical in his approach to devotion. 
Our life is a false nature, ' $t$ is not in

The harmony of things, --this hard decree,

This uneradicable taint of sin,

This boundless upas, this all-blasting tree

Whose root is earth, whose leaves and branches be

The skies which rain their plagues on men like dew-

Disease, death, bondage-all the woes we see-

And worse, the woes we see not-which throb through

The immedicable soul, with heart-aches ever new. ${ }^{17}$

Passages such as these have led Edward Marjorum to declare that Byron's Christianity was Judaic. "That Byron's conception of the deity was primarily Hebraic rather than Christian is rendered even more apparent by his conception of the nature and personality of Christ," Marjorum writes. "Byron did not show much interest in the New Testament, with its message of comfort and hope, until later years. He did not mention Christ in his poetry until he was twenty-three." ${ }^{\prime 18}$

According to Lady Melbourne, Byron lived in the Albany in a state of arrested religious development, where a painting once hung entitled "Joseph and Potiphar's Wife" by Orazio Gentileschi. They wrote about this painting and Lady Melbourne planted the seed of a reference to the story of Joseph that found expression five years later, after she died, and he began composing Don Juan. Perhaps for this reason, Byron alluded to the story of Joseph several times: in the "Bride of Abydos", for example, he quoted the Koran and Genesis. In Genesis, a woman accuses Joseph of rape-she remains unnamed, called simply, "Potiphar's Wife." The Koran by contrast, offers a conciliatory approach to the women who marvel at Joseph's great beauty, Zulaikha, and cut their hands while peeling an orange. Throughout his life, Byron was haunted by the fact that women were the seducers and men (particularly he) the seduced, dating back to his sexual molestation by May Gray and his pursuit by Lady Caroline Lamb, both devoted to him in their twisted ways. In the "Bride of Abydos," the beautiful heroine Zulaikha is more capable than the passive and effeminate (because kept as a slave) Selim, whose curly haired appearance resembles Joseph in the Old Testament. ${ }^{19}$ Dominated by his mother Donna Inez, seduced by the unhappily married Donna Julia, Don Juan (or Jew-one, as it is pronounced by the English), a mockery of the swash-buckling Latin Lover, is a parody of devotion, a hero roughly handled by the women who molest him and then ask, "Christian, 
canst thou love?"20 At certain points, it is not clear that he is a Christian; his lineage may be that of a marisco or converso ("free of every stain/ of Moor or Hebrew blood," the narrator quips facetiously). ${ }^{21}$ His name sounds different than it reads. "Juan" with a soft "J" in Spanish or "Jew-one", according to British pronunciation, even as it suggests the expulsion of the Moriscos from Spain between 1609 and 1615, perhaps accounting for the "curly-headed" Juan. ${ }^{22}$ Byron's Juan is thus chosen in both a religious and nationalist sense: he may not be the "true one", but his name sounds sonorously with Don Juan.

In Byron as Skeptic and Believer, Edward Marjorum provides perhaps the most balanced insight into Byron's fluctuations of belief. He notes that Byron came late to believe in the divinity of Jesus Christ. For most of his life, until 23, he was Hebraic in his understanding of God. God had created a world of suffering and man was left to fend for himself. ${ }^{23}$ Poetry could provide a humanist alternative to religious belief, for Byron in creating lived a "being more intense" (3:6:46). But even poetry was mere scribbling and acts, rather than just words, compelled Byron to relinquish the sword for the pen at Messolonghi, Greece, where he assisted the cause of Greek independence. It was in the pursuit of intense emotions, a philosophy acknowledged by Walter Pater and John Ruskin, that Byron was most devoted.

Byron mocks devotion in Cain, when Cain criticizes Adam for praying too "loudly" (1:33). What he mocked was not religious belief so much as rote learning. Thomas Moore, who fought for Catholic emancipation, felt that Cain had stuck a sword in the heart of religious devotion that would not soon heal. "Cain is wonderful-terrible-never to be forgotten," Moore wrote. "If I am not mistaken, it will sink deep into the world's heart; and while many will shudder at its blasphemy, all must fall prostrate before its grandeur." ${ }^{4}$ "What think you of Lord Byron now?" Shelley wrote to John Gisborne regarding Cain. "Space wondered less at the swift and fair creations of God, when he grew weary of vacancy, than I at the late works of this spirit of an angel in the mortal paradise of a decaying body. So, I think-let the world envy while it admires, as it may." ${ }^{25}$ Marchand notes that Shelley continued to hold "exaggerated views of the merits of Cain". In a century where literature began to replace devotion, as Matthew Arnold predicted it would, the spirit of rivalry led to the production of secular works of holiness. All became disciples of Lord Byron, even Tennyson, who scribbled "Byron is dead" on a rock, as if he were Nietzsche announcing the death of God in Thus Spake Zarathrustra. ${ }^{26}$ "I do not write-I have lived too long near Lord Byron and the sun has extinguished the glow-worm," Shelley noted in 
Italy (1:951). Though he knew Shelley despised social conventions, Byron criticized Shelley's atheism (wonderfully captured in Shelley's own "Julian and Maddalo") and praised, of all things, Shelley's drawing-room manners.

\section{Personal Devotion}

Many writers were personally devoted to Byron's life and example, as much as they were to his poetry. These include Polish freedom fighters such as Adam Miekiwicz, writers such as Ugo Foscolo (Dei Sepolcri), Johann Wolfgang von Goethe, Mikhail Lermontov (Hero of Our Time), Alexander Pushkin (Eugene Onegin, which is inspired by Don Juan) and Alessandro Manzoni (The Betrothed). He also influenced Hector Berlioz to pen ("Harold in Italy"), Eugene Delacroix's two versions of "Lament of Tasso", Ford Madox Brown's "Manfred on the Jungfrau" (1842), and John Martin's two studies of Manfred. "Prominent adaptations of Byron's texts, include Donizetti’s Marino Faliero, Verdi's Two Foscari, and Il corsaro, and Rossini's Le siège de Corinth, which, while not always faithful or based solely on Byron's works, show audience the identification of Byron with liberty." ${ }^{27}$ William E. West painted his portrait, as did Thomas Phillips, the latter in Albanian dress (1814), thereby showcasing Byron's devotional cosmopolitanism. Thorwaldson and Bernini cast him in stone; monuments to him in the Villa Borghese and in Athens attest to his world historical importance. England buried him in Hucknall Church, with a plaque at Poet's Corner (added only in 1969, after a rejected attempt in 1924), while Messolonghi kept his lungs in San Spiridione ${ }^{28}$ or what was left of them.

Byron was devoted to humanity in its full dimensions and delighted in self-contradiction. He could admire Ali Pasha's political independence and integrity in Albania while noting his savagery and sexual advances. He so admired Leigh Hunt's commitment to political truth that he visited him in person in 1813, both rising above and subtly reinforcing concerns of social class as he would do again when he worked with Hunt on The Liberal in 1821. Though considered a great womanizer, he felt himself more raped and pillaged than Helen of Troy, despite, like Paris, being Quixotic and destructive, to himself and others, in his pursuit of beauty. "I should like to know who has been carried off-except poor dear me," he wrote to Richard Hoppner, after being accused of mistreating an Italian woman bound for a convent, "-I have been more ravished myself than anybody since the Trojan war." ${ }^{29}$ In Italy and Greece, he shifted dramatically between masks of idealism 
and cynicism, struggling to see the political struggle for independence in a clear light.

Devotion in Manfred is also subject to this shifting scale of skepticism and idealism. The conventionally pious Chamois hunter and Abbott contrasts with Manfred's devotion to the beauty of Astarte: "I loved her and destroyed her," he notes. ${ }^{30}$ Devotion becomes a form of annihilation: "each man kills the thing he loves," as the Byronic, dandyish, and flamboyant Oscar Wilde put it in "The Ballad of Reading Gaol." The summoning of astral projections and pentagrams in the form of Manfred's seven spirits recalls the Enlightenment fascination with the occult. Zoroastriaism elevates brother/ sister love above all others. Byron was an Enlightenment comparativist in this sense, like Voltaire and Montesquieu, from whose Persian Letters he derived the appropriate anecdote concerning Astarte and Aspheridon and the justification for "incest". ${ }^{32}$ In his tolerance of all religions, Byron was that unlikely thing, a mason (like his heroes Robert Burns, George Washington, and Alexander Pope), a form of devotion that he, like his grandfather, adhered to all his life. ${ }^{33}$ Whether he fought with the Carbonari or joined the Americani lodge in the forests of Ravenna, Byron recognized that freemasonry could draw on divinity and secular forms of justice to effect political change. ${ }^{34}$ At the same time, he ridiculed masonic belief, exhibiting the ironic attitude towards religion explored earlier in this essay in Cain and in Don Juan. ${ }^{35} \mathrm{He}$ piqued himself on writing a "Human" poem in Don Juan, rather than a "divine" one, telling his critics, who tried to censor him, that you "shan't make Canticles of my cantos." 36

While a traditional approach to Byron and devotion might consider Byron's expressions of religious faith, another might include those devoted to him, the fact that this incorrigible sinner inspired devotion at all. A single mother, outrageously shorn of her fortune by Byron's rakish father, Catherine Byron restricted herself to 200 pounds per year while granting her son a generous allowance of 500, even paying for clothes and other necessities so they would not affect his annual allowance. ${ }^{37}$ She placed him in the company of a relative stranger and neighbor at Southwell, Elizabeth Pigot, only to find that her son preferred Pigot and avoided his mother, favoring even the family lawyer John Hanson's company for the Christmas holidays. She was aware that Elizabeth Pigot mocked her for her uncouth manner, as did Augusta Leigh. Indeed, Byron's sense of devotion was warped by triangulation throughout his life-so many adored and were devoted to 
him that he hurt the feelings of those clambering for his favor. Though he professed devotion to Lady Caroline Lamb, Lady Frances Webster, Lady Oxford, and even Lady Melbourne, they were all married, and he sometimes compromised male friendships with their husbands to pursue these women; his affairs were not enactments of devotion so much as violations of it, having more in common with Valmont's conduct with women (Laclos' Dangerous Liaisons) than Wolmar's (Rousseau's Julie: Ou la Nouvelle Hélö̈se). His closest friendships involved such familial betrayals. "Byron, your mother is a fool," one Harrovian noted. "I know it," Byron responded. ${ }^{38}$

Byron's vexed sense of devotion can also be found in his interactions with John Murray, his Scottish publisher, who acted as a father figure to the poet and cultivated his career in painstaking ways, ordering tooth powder, adopting his bulldog sent from Italy and suggesting gifts he might give to fellow poets, like Walter Scott. Then there is Isaac Disraeli, who dubbed him a genius in his Literary Character of Men of Genius. ${ }^{39}$ At a second order would be his close correspondents, Elizabeth Pigot, Lady Melbourne, John Cam Hobhouse, Thomas Moore and others whose friendship survived scandal and exile. Moore became his biographer; Hobhouse, the sacred guardian of his reputation, ordering the burning of his memoirs, along with John Murray, to avoid scandal. Byron's close friendships with John Edleston, Robert Rushton, Lukas Chalandritsanos, and others, even Augusta Leigh, bespeak his passionate heart and capacity for human warmth, forgiveness, and love. His most memorable poem, completed on his 36th year, closes with this memorable line, "still let me love," a clear expression of the humanistic devotion his poetry incarnated. Finally, one must contend with the devoted love letters he inspired. The list is not unlike the recitative aria from Don Juan, sung by his valet, Leporello. ${ }^{40}$ From a woman in Spain came a long braid of hair kept lovingly for him by his publisher; from Caroline Lamb came a satire entitled Glenarvon; Mary Shelley depicted him as Lord Raymond in The Last Man, ${ }^{41}$ while Thomas Medwin and Lady Blessington ${ }^{42}$ recorded and altered his every word when they did not outright invent it. There were those who rivaled him and those who imitated him. John Polidori, the Edinburgh Physician, wrote the Vampyre in part because of Byron's magnetic storytelling in 1816 and reading aloud from Fantasmagoriana, a French anthology of German ghost stories published in 1812. Such was the nature of Edward Trelawny's devotion that he abandoned Byron in Greece and predicted that he would have outshined Byron had he lived any longer; ${ }^{43}$ William Hazlitt similarly criticized Byron for spending too much time at Cephalonia, when 
he should have been on the Greek mainland helping prosecute the war. ${ }^{44}$ The leftists Byron assembled around him included Leigh Hunt and Percy Shelley, with whom he collaborated on a journal entitled The Liberal, the first use of that word as a political noun in English.

Collecting devotees, painters and sculptors, Byron showed his devotion to Newstead, his ancestral estate, which he delayed selling as long as possible. In Greece, Byron became devoted to a young Turkish mother and her girl, who he planned to send to Teresa Guiccioli or Lady Byron to raise. The impertinence of such a gesture struck even Byron and he contented himself, instead, with buying her dresses and rebuking her for her behavior when she became too proud, much as he did Allegra, before she died of a fever in a convent. Despite his wayward disposition and capricious temper, Byron exhibited a devotion to his children, to Ada and Allegra, that is fully apparent in his letters. His politics of feeling, which he once explained by comparing his conduct to "A Sentimental Journey Through Italy and France" by Laurence Sterne, shows him obeying his feelings to the very end. "Ultimately, to avoid separating mother and daughter, Byron sent both to Cephalonia to be cared for temporarily by his devout friend Dr. James Kennedy". ${ }^{4}$

Most discussions of Byron's devotion begin and end with doctrinal matters. Delirious with fever, Byron told Parry: "I fancy myself a Jew, a Mahometan, and a Christian of every profession of faith. Eternity and space are before me; but on this subject, thank God, I am happy and at ease. The thought of living eternally, of again reviving, is a great pleasure." "It is rather curious that it was only to the rough old soldier Parry that Byron talked of religion in his last days," Leslie Marchand notes. ${ }^{46}$ Dr. Millingen recorded: "It is with infinite regret I must state, that, although I seldom left Lord Byron's pillow during the latter part of his illness, I did not hear him make any, even the smallest, mention of religion. At one moment I heard him say: "Shall I sue for mercy? After a long pause he added: "Come, come, no weakness! Let's be a man to the last". ${ }^{47}$ Re-enacting the final scene from Manfred, as this passage does, Byron attempts to replay the hero's line: “Old Man 'tis not so difficult to die." ${ }^{48}$ Against such evidence of existential self-reliance, we have the bible he carried with him and kept near his bedside at Messolonghi. We have his conversations with the Methodist William Kennedy, which became further proof that the author of "Heaven and Earth" and "Cain" remained concerned with eschatological matters to the end.

Published in 1957, Leslie Marchand's biography of Byron adopts a worldly, wry, and tolerant view of Byron's peccadilloes, both sexual and religious, 
without naming his bi-sexuality for what it was. This has been corrected, perhaps even distorted, by some recent well-written biographies. ${ }^{49}$ Yet 20th century secularism is not the best vantage point from which to understand Byron's devotion, raised as he was, in the Scottish Highlands (even the narrator of Don Juan is a moderate Presbyterian). Calvinism led Byron to become superstitious. "He was born with a caul and, what was worse, with a deformed right foot," Marchand reports. Prothero notes that the caul, supposed by sailors to be a lucky charm against drowning, was sold by the nurse, Mrs. Mills, to Captain James Hanson, brother of John Hanson. But it did not save him when H.M.S. Brazen foundered in a storm off Newhaven on January 26, 1800 (I:25). We can laugh at such things, but "it is difficult to know whether Byron's mind was wandering, whether he was serious, or whether he was merely trying to play a practical joke on the doctors when he asked Dr. Millingen to do him the favor of inquiring in the town for an old and ugly witch," Marchand notes. "Never mind whether I am superstitious or not," Byron stated, "but I again entreat of you to bring me the most celebrated one there is, in order that she may examine whether this sudden loss of my health does not depend on the evil eye. She may devise some means to dissolve the spell." ${ }^{50}$ Byron had been told in Scotland, by a soothsayer, to fear his 37 th year.

Predictions and prophecies aside, Byron's sense of devotion to his dog, Boatswain, who he commemorated in a misanthropic monument at Newstead; to Lyon, the Newfoundland that accompanied his body back to England; to his pet bear, who "sat" for a fellowship at Cambridge; and to his wife, Teresa Guiccioli, and children, who he loved in his own fashion, with a sense of devotion that transcends more conventionally wed spouses. In fact, Byron showed a tremendous capacity for devotion to animals, people, causes, countries, and poetry, not surprising in a man whose family crest was "Crede Byron." "You always may", John Ruskin once wrote, ${ }^{51}$ and one proof of it is in the many monuments and statues to him that one finds throughout the world.

\section{Political Devotion}

It is perhaps most helpful to consider Byron's final act of devotion: to the cause of Greek independence. Turkish occupation of the Acropolis and various indignities, advertised in Byron's Childe Harold's Pilgrimage and Don Juan, helped foment anger against an occupying force, the Ottoman 
Empire, that taxed Greek cities and dampened trade and profit. Perhaps the Greek War of Independence was precipitated by their efforts to control the warlord Ali Pasha in Albania, whose activities in Western Greece proved to be the ultimate undoing of the Ottoman Empire. As a 22 year old aristocrat on the grand tour, Byron had visited Ali Pasha at his home in Janina and died at 36 devoted to a war of independence that Pasha helped precipitate. About the Greek war there were different opinions and different response. Sectarianism ruled the day with Westernized Greeks competing with klefts for British support. English parliamentarians highlighted the Philhellenic cause while suppressing Greek atrocities, as William St. Clair has shown. The admiration for Greek sculpture and buildings, such as the Parthenon, helped to fuel the Philhellenism that mistakenly viewed Greeks as the modern descendants of ancient Athenians like Pericles.

Byron felt compelled to join the Greek cause when he assured his friend John Cam Hobhouse, who visited him in Italy, that Greek independence was a cause worth fighting for. Joining the London Greek committee, Byron confessed to Teresa Guiccioli, his mistress at the time, that he could not abandon his declared purpose without embarrassment. In letters to his friends, he declared that a man should be something more than a fancarrier to a woman and a scribbler of verses. And so, he set out on his last adventure, with Teresa's brother Pietro, Edward Trelawny, and his servant, the valet Fletcher.

Some felt Byron was grand-standing. Edward Trelawny noted, with regret, his trifling his time away at Cephalonia, while others have recently mocked the Byron brigade with its Homeric hats carefully protected in pink boxes. What distinguished Byron's devotion to Greece was his willingness to spend his own fortune raising Suliote troops. He not only maintained the Suliotes for a year, but contributed more than the whole government. ${ }^{52}$ Byron's largesse in Greece quickly made him the prey of financial opportunists. He had to choose between the scholarly Alexander Mavrocordato, a Constantinople nobleman and friend of Byron and Shelley ${ }^{53}$ and the more swashbuckling Androutses Odysseus, captain of Greek irregulars (the most powerful man in Eastern Greece), who Edward Trelawny ultimately joined. Before he died of two near epileptic seizures, and from the blood-letting of Dr. Millingen, Byron established his reputation in Greece to such an extent that there was talk that he might become King, but this was unlikely. On his death, a day of mourning was observed. Throughout Greece, in the Garden of Heroes in Messolonghi and near Hadrian's arch in Athens, one sees statues 
commemorating his sacrifice, which secured British support for a loan to keep the Greek government solvent and prompted French philhellenism and support.

This essay has explored Byron's devotion to animals, friendships, religious doctrines, poetry, and finally to European liberalism and nationalism. What distinguishes him from other Romantic poets, however, is his decision to choose the moment of his death, to die fighting for Greek independence and to spend his personal fortune doing so. It was a gesture, if theatrical, that showed the meaning of devotion and Philhellenism in all its dimensions.

\section{Notes}

1. George Gordon, Lord Byron, "The Vision of Judgment", CPW, 7 vols. ed. by Jerome J. McGann, 6:12.

2. "devotion, n.". OED Online. June 2017. Oxford University Press. http://www.oed. $\mathrm{com} /$ view/Entry/51579? redirectedFrom=devotion (accessed November 30, 2017). "devout, adj. and n.". OED Online. June 2017. Oxford University Press. http://www. oed.com/view/Entry/51604?rskey=qllE8h\&result=1 (accessed November 30, 2017).

3. Jerome Hamilton Buckley, The Victorian Temper: A Study in Literary Culture (Cambridge: Cambridge UP, 1951), 25.

4. For an alternative, and deliberately polemical view, see G. Wilson Knight, Lord Byron: Christian Virtues (New York: Oxford UP, 1953).

5. Robert Southey, Life and Correspondence of Robert Southey, 6 vols (Ann Arbor: University of Michigan, 2006) 5.178, quoted in David Roessel, In Byron's Shadow: Modern Greece in the English and American Imagination (Oxford: Oxford U P, 2002), 91.

6. John Keats, The Letters of John Keats, ed. by Robert Gittings (Oxford: Oxford UP, 1970; Letter of Sunday 14 Feb. -Monday 3 May 1819), 249.

7. Matthew Arnold, "Byron," in Poetry and Criticism of Matthew Arnold, edited with an introduction and notes by A. Dwight Culler (Boston: Houghton Mifflin Company, 1961), 347-362.

8. Raymond Williams, Culture and Society: 1780-1950 (New York: Columbia University Press, 1957), 191.

9. T.E. Hulme, "Romanticism and Classicism" In Speculations (London: Routledge \& Paul, 1965).

10. Michael Cooke, The Blind Man Traces The Circle: On the Patterns and Philosophy of Byron's Poetry (Princeton: Princeton UP, 1969); and James Kennedy, Conversations on Religion with Lord Byron (New York: Forgotten Books, 2012).

11. Terence Hoagwood, Byron's Dialectic: Skepticism and the Critique of Culture (Lewisburg: Bucknell UP, 1993); Emily Bernhard Jackson, The Development of Byron's Philosophy of Knowledge: Certain in Uncertainty (London: Palgrave, 2010); Anthony Howe, Byron and the Forms of Thought (Liverpool: Liverpool UP, 2013). 


\section{Gross}

12. "I would rather have the fame of Childe Harold for three years than an Immortality of Don Juan!: - The truth \{is that it is too true - and the women hate everything which strips off the tinsel of Sentiment $-\&$ they are right - - or it would rob them of their weapons"; October 19, 1820, BLJ *:**.

13. Manfred, 1:2:297-303 (1816) in George Gordon, Lord Byron, Complete Poetic Works, ed. by Jerome J. McGann, 7 vols. (Oxford: Oxford UP, 1981-88).

14. For the discussion of Manichees's philosophical and religious doctrines and Augustine's response, see Augustine of Hippo, Confessions, second edition, trans. by F.J. Sheed; introduction by Peter Brown (New York: Hackett, 2006), Books 3, 5, 7, 8-10. See also Todd Breyfogle, "No Changing Nor Shadow," in A Reader's Companion to Augustine's Confessions, ed. by Kim Paffenroth and Robert Peter Kennedy (Louisville: John Knox Press, 2003), 37.

15. Jean-Jacques Rousseau, On the Social Contract, with Geneva Manuscript and Political Economy, ed. by Roger D. Masters, trans. by Judith R. Masters (New York: St. Martin's 1978), 46.

16. George Gordon, Lord Byron, Byron's Letters and Journals, 12 vols, ed. by Leslie Marchand (Boston: Harvard UP, 1971-1978), 1:238.

17. George Gordon, Lord Byron, Byron Complete Works, ed. by Jerome J. McGann, 7 vols. (Oxford: Oxford UP, 1981-1988), Childe Harold, 4:126 (1818).

18. Edward Wayne Marjarum, Byron as Skeptic and Believer (Princeton: Princeton UP, 1938), 11.

19. Jonathan David Gross, Byron: The Erotic Liberal (Lanham, MD: Rowman and Littlefield, 2001), 60-62.

20. George Gordon, Lord Byron, Don Juan in Complete Poetic Works, ed. by Jerome J. McGann (Oxford: Oxford UP, 1986), DJ, 5:116.

21. Byron's Don Juan, CPW 5:1:9.

22. Matthew Carr, Blood and Faith: The Purging of Muslim Spain (New York: The New Press, 2013); "A little curly-headed, good-for-nothing,/And mischief-making monkey from his birth;" CPW 5:1:25.

23. Marjarum, 11.

24. Leslie Marchand, Byron: A Biography, 3 vols. (New York: Alfred A. Knopf, 1957), $1: 952$.

25. Ibid., 1:951.

26. Buckley, 68. Friedrich Nietzsche, The Gay Science, with a Prelude of Rhymes and an Appendix of Songs, trans. By Walter Kaufmann, Section 125, “The Joyful Wisdom” (New York: Vintage, 1974); Thus Spake Zarathustra, trans. By R. J. Hollingdale (New York: Penguin Classics edition, 1969), 41.

27. Arnold Schmidt, Byron and the Rhetoric of Nationalism (London: Palgrave Macmillan, 2010), 62.

28. Leslie Marchand, 3:1241.

29. BLJ, October 29,$1819 ; 6: 237$.

30. Manfred, CPW, 3:2:2:124.

31. Oscar Wilde, “The Ballad of Reading Gaol” (London: Serenity, 2009), ln 30.

32. Alan Richardson, A Mental Theatre: Poetic Drama and Consciousness in the Romantic 
Age (Penn State Press, 1988); “Astarté: Byron's 'Manfred’ and Montesquieu's 'Lettres Persanes," Keats-Shelley Journal, Vol. 40 (1991), 19-22.

33. "Byron: A Poetic Revolutionary in the Century of Words", in Profiles of Revolutionaries in Atlantic History, 1700-1850, edited by R. William Weisberger, Dennis P. Hupchick, and David L. Anderson. Social Science Monographs, Boulder, distributed by Columbia University Press, 2007, 216-238.

34. William St. Clair, That Greece Might Still be Free: the Philhellenes in the War of Independence (London: Oxford UP, 1972), 31, 259. Jonathan Gross, "The Vulgar Must Not Share It," in Freemasonry on Both Sides of the Atlantic: Essays concerning the Craft in the British Isles, Europe, the United States, and Mexico, edited by R. William Weisberger, Wallace McLeod, S. Brent Morris (Boulder, Colorado: East European Monographs, 2002), 347-375.

35. CPW 5:6:54:425-432.

36. Leslie Marchand, 2:770.

37. Doris Langley Moore, Lord Byron: Accounts Rendered (London: John Murray, 1974) cited in Megan Boyes, My Amiable Mamma: A biography of Mrs. Catherine Gordon Byron, the Poet's Mother (London, 1991), 111.

38. Leslie Marchand, Byron: A Biography, 1:62; Paul Elledge, Lord Byron at Harrow School: Speaking Out, Talking Back, Acting Up, Bowing Out (Baltimore: Johns Hopkins, 2000), 59.

39. Isaac Disraeli. Literary Character of Men of Genius, 3rd edition (London: John Murray, 1818).

40. Jonathan Gross, “'One for Whom the Opera is By No Means New’: Byron's Debt to Mozart's Don Giovanni in 'Canto 4' of Don Juan," Ars Lyrica: Journal of the Lyrica Society for Word-Music Relations (2011): Volume 20, 9-19.

41. Mary Shelley, The Last Man, ed. by Ann McWhir (Peterloo, Ontario: Broadview Press, 1996).

42. Lady Blessington, Lady Blessington's Conversations of Lord Byron, edited, with an Introduction and notes, by Ernest J. Lovell (Princeton: Princeton UP, 1969); Thomas Medwin, Conversations with Lord Byron: Noted During a Residence with his Lordship at Pisa (London: Henry Holborn, 1824).

43. Edward Trelawny, Records of Shelley, Byron, and the Author (New York: New York Review of Books, 2000).

44. William Hazlitt, "Byron" in The Spirit of the Age (1823), The Complete Works of William Hazlitt ed. by P.P. Howe, after the edition of A.R. Waller and Arnold Glover (London: J.M. Dent, 1930).

45. David Brewer, The Greek War of Independence: The Struggle for Freedom from Ottoman Oppression and the Birth of the Modern Greek Nation (New York: Overlook Press, 2001), 214.

46. Marchand, 3:1217.

47. Marchand 3:1217.

48. George Gordon, Lord Byron. "Manfred”, CPW 3:3:4:ln. 173.

49. Phyllis Grosskurth, Byron: The Flawed Angel (Boston: Houghton Mifflin, 1957); Benita Eisler, Byron: Child of Passion, Fool of Fame (New York: Vintage, 2000), Fiona 


\section{Gross}

MacArthy, Byron: Life and Legend (New York: Farrar, Straus, and Giroux, 2002).

50. Marchand 3:1216.

51. John Ruskin, On the Old Road: a Collection of Miscellaneous Essays, Pamphlets. Ruskin suggests reading Byron by his own motto, “'Trust Byron.' You always may; and the common smooth-countenanced man of the world is guiltier in the precise measure of your higher esteem for him," 124.

52. Marchand, 3:1154

53. St. Clair, That Greece Might Still be Free, 166. 